\title{
THE MEDIATING EFFECT OF TEAM COOPERATION ON TACIT KNOWLEDGE TRANSFER AND INTERPERSONAL TRUST
}

\author{
Helena BULIŃSKA-STANGRECKA (1) ${ }^{*}$, Anna BAGIEŃSKA (D2 ${ }^{2}$ \\ ${ }^{I}$ Faculty of Administration and Social Sciences, Warsaw University of Technology, \\ Plac Politechniki Street 1, 00-661 Warszawa, Poland \\ ${ }^{2}$ Faculty of Engineering Management, Bialystok University of Technology, \\ Wiejska Street 45, 15-351 Bialystok, Poland \\ *E-mail: h.bulinska-stangrecka@ans.pw.edu.pl
}

\begin{abstract}
Purpose - this article aims to examine how teamwork cooperation mediates the relationship between interpersonal trust and tacit knowledge transfer.

Research methodology - the paper uses data obtained from a survey conducted on 175 employees from the telecommunications sector. The multiplied regression method was applied to analyse the data according to the mediation analysis.

Findings - the findings show that interpersonal trust predicts tacit knowledge transfer and team cooperation mediates this relationship. The results indicate the importance of nurturing positive, trusting relations among employees in organisations and the necessity of working interactions.

Research limitations - the limitation of this research is related to the relatively small research sample. Further research could be conducted on a higher number of respondents and could cover different sectors. Additional development of presented research might include cross-cultural analysis.

Originality/Value - this paper contributes to the literature of management by providing the empirical confirmation of the SET-based model that concerns the mechanism of tacit knowledge transfer. The practical implications highlight the importance of common collaborative experience and interpersonal trust that facilitates trust among co-workers and consequently influences tacit knowledge transfer.
\end{abstract}

Keywords: trust, tacit knowledge, knowledge transfer, knowledge management.

JEL Classification: M54, M14, M21.

Conference topic: Contemporary Organizations Development Management.

\section{Introduction}

While the contemporary economy emphasises the value of intangible resources, the ability to manage tacit knowledge is a core factor that affects organisational performance (Pathirage, Amaratunga, \& Haigh, 2007). Knowledge transfer is one of the crucial elements that affect innovative organisational capability (When \& Montalvo, 2018; Luo, Lui, \& Kim, 2017; Krogh, Ichijo, \& Nonaka, 2000; Kogut \& Zander, 1996) and is related to team performance (Wang \& Wang, 2012).

Even though some research acknowledges the influence of trust on knowledge transfer (Rutten, Blaas-Franken, \& Martin, 2016; Burnette, 2017), the issue has not been thoroughly examined. The literature analysis indicates that much research has verified the role of tacit knowledge and trust in business-to-business relations (Hefferan, 2004; Inkpen, \& Tsang, 2005). Additionally, trust has mostly been studied from the organisational perspective, but not the interpersonal perspective (Christie, Jordan, \& Troth, 2015; Sankowska \& Siudak, 2015; Bachmann et al., 2015). The links between trust in fellow employees and its influence on knowledge transfer have not been sufficiently studied.

Consequently, as its role in strategic planning and performance has been already acknowledged (Bennett, 1998; Blattberg \& Hoch, 1990; Brockmann \& Anthony, 1998). This research relates primarily to tacit knowledge, which is considered to be crucial for an organisation's success and development.

Tacit knowledge is a specific kind of knowledge that is based on one's experience and practice (Nonaka \& Takeuchi, 1995) and is rooted in individual skills. Due to its nature, it is difficult to codify or share (Polanyi, 1966). Additionally, tacit knowledge relates to an individual's know-how, which usually is regarded as a valuable asset in the

(C) 2019 Authors. Published by VGTU Press. This is an open-access article distributed under the terms of the Creative Commons Attribution (http://creativecommons.org/licenses/by/4.0/) License, which permits unrestricted use, distribution, and reproduction in any medium, provided the original author and source are credited. 

and interpersonal trust

labour market (Brown, Hesketh, \& Wiliams, 2003; Osinski, Selig, \& Matos, 2017). A major challenge for contemporary managers is related to the codification and transfer of tacit knowledge (Zawiła-Niedźwiecki, 2015). However, empirical evidence indicates that employees are usually reluctant to share it (Al-Alawi et al., 2007). Social Exchange Theory (SET) explains how to facilitate tacit knowledge transfer. In the view of SET, longitudinal relationships among employees reinforce the exchange process (Emerson, 1976). Trust is acknowledged as a cornerstone of the social exchange relationship (Blau, 1964).

Furthermore, trust emerges through social interactions and develops the grounds for mutual, reciprocal bonds, which in effect enables tacit knowledge sharing. Trust plays a significant role in this process. In the extant literature, the relations between trust and tacit knowledge sharing and use has been examined (Holste \& Fields, 2010); however, the interpersonal perspective has not been sufficiently explored.

This study addresses the issue of how interpersonal trust affects tacit knowledge transfer. It explores the links between trust and tacit knowledge transfer mediated via team cooperation.

Besides, this paper uses the framework of Social Constructivist Theory (SCT) developed by Vygotsky (1962) to analyse the role of social interaction in the process of tacit knowledge sharing. SCT assumes that knowledge is not merely transferred between involved actors, but rather is co-created by social interactions. This suggests that collaborative actions and collective experience including group interactions are necessary conditions of tacit knowledge sharing among employees. The effective dissemination of tacit knowledge can be enhanced within a group that is connected by mutual relations. Such mutual interactions are established on the foundation of collective experience and prior cooperation. Therefore, the mediating role of team collaboration in tacit knowledge transfer has been included in this research.

Firstly, this paper presents a research framework and literature review concerning knowledge transfer, team cooperation and trust. Secondly, it describes the method and measures. Finally, it reports the results of qualitative research and discusses the findings.

\section{Theoretical development}

\subsection{Trust}

Trust is a broad construct that has various definitions in the scientific literature (McEvily \& Tortoriello, 2011; Ejdys, 2018). The concept of trust can be generally understood as confidence among one party that another party will behave in a reliable manner (Morgan \& Hunt, 1994). Trust is perceived as the propensity to expect a positive outcome from another party's future behaviour (Mayer, Davis, \& Schoorman, 1995; McAllister, 1995; Brattström \& Bachmann, 2017). It has been assumed that trust is learned (Danielson \& Holm, 2007). It can be categorised into basic dimensions depending on the factor influencing a person's attitudes, i.e. cognitive trust and affective trust (Johnson \& Grayson, 2005). All in all, trust can be defined as an individual predisposition to depend on the anticipated actions of someone else (Ferguson \& Peterson, 2015).

According to Stranes, Truhon, and McCarthy (2015) the research on trust in organizations can be divided into three main frameworks: inter-organizational trust (Davenport, De Long, \& Beers, 1998; McEvily, Zaheer, \& Kamal, 2017) organizational trust (Verburg, Nienaber, Searle, Weibel, Den Hartog, \& Rupp, 2018) and interpersonal trust (Gomez \& Rosen, 2001; Kong, Dirks, \& Ferrin, 2014). Interpersonal trust in the organisational context concerns relations between two individuals, whether they are coworkers or a subordinate and a supervisor (Gupta et al., 2016). From the organisational perspective, interpersonal trust can be interpreted as a control mechanism that enables cooperation among coworkers (Niu, 2010) or between subordinates and managers (Joseph \& Winston, 2004). Empirical evidence suggests that the relationship among team members predicts the development of interpersonal trust (BulińskaStangrecka \& Bagieńska, 2018). The general impact of trust on an organisation and its members have been recognised (Lohikoski, Kujala, Haapasalo, Aaltonen, \& Ala-Mursula, 2016). The comparison of trust levels in organisations implies that employees in high-trust organisations are more open and willing to participate and cooperate. However, employees in low-trust enterprises are usually more defensive, more jealous, more likely to scapegoat others, and more unwilling to share ideas (Bruhn, 2001). Therefore, trust is an essential condition for developing successful work environments that enable cooperation, especially in knowledge-based organisations (Pinho, 2012). This paper focuses on interpersonal trust and its consequences for tacit knowledge transfer.

\subsection{Tacit knowledge}

The most common differentiation of types of organisational knowledge distinguishes explicit and tacit knowledge (Nonaka \& Takeuchi, 1995). Explicit knowledge is easily codified and disseminated. In contrast, tacit knowledge, which arises from personal experience, is difficult to be systematised and spread to other persons (Foos, Schum, \& Rothenberg 2006). Polyani has defined it as a type of knowledge which cannot be codified or explained (1966). Tacit knowledge can be categorised into two categories: technical, covering know-how skills, and cognitive, which consists of perceptions, experiences, and mental models (Nonoka \& Takeuchi, 1995, pp. 8). It is generally more difficult to 
exchange tacit than explicit knowledge. It can be compared to know-how (Smith, 2001) and learned through observation, practice or imitation (Choo, 2000). Tacit knowledge has been associated with effective organisational performance (Haldin-Herrgard, 2000; Gomezelj \& Antončič, 2015).

\subsection{Tacit knowledge transfer}

Knowledge transfer can be defined as a process in which one person receives and reuses obtained knowledge (Kumar $\&$ Ganesh, 2009). It refers to the sharing of information between involved parties (usually a source and a receiver) (Grover \& Davenport, 2001); it can be described as knowledge sharing between members of an organisation (DeLong, 2004). All in all, it is a process of information exchange.

This mechanism of tacit knowledge transfer can be explained using the SET framework, which states that individuals are motivated in their behaviours by the anticipated rewards from others (Emerson, 1976). SET explains the mechanisms that drive reciprocal relations between individuals and is the underlying assumption that represents the nature of these interactive processes (Gouldner, 1960). According to SET, employees are oriented to the expected results; therefore, if they trust that others will not betray their interest, they will be more open to engaging in such a relationship. Since SET is founded on trust (Roloff, 1981), mutual confidence in the goodwill of others helps to establish a supportive environment that enhances reciprocal processes among employees. Moreover, trust decreases the perceived risk of social exchange (Metzger, 2004). Furthermore, employees tend to join an exchange relationship which is established on trust.

Numerous studies have demonstrated that trust facilitates knowledge sharing (Savolainen \& Häkkinen, 2011; Boateng, Agyemang, Okoe, \& Mensah, 2014; Zhao, Zhu, Peng, Xu, \& Liu, 2018; Yin \& Jahanshahi, 2018, Raudeliūnienè, Meidutè-Kavaliauskienè, \& Vileikis, 2016). Interpersonal trust among team members usually results in better knowledge exchange, which is especially important regarding tacit knowledge transfer. People are more open to sharing their tacit knowledge when they expect it to be beneficial. Trust plays a crucial role in such an exchange (Ng, 2016; Smaliukienè, Bekešienè, Chlivickas, \& Magyla, 2017). In other words, trust-based relations enhance the transfer of tacit knowledge between employees. Hence the following hypothesis was formulated:

H1: Trust between coworkers is positively associated with tacit knowledge transfer.

\subsection{Trust and team cooperation}

Cooperation is understood as a process in which employees in an organisation work collaboratively on a shared task in order to accomplish a common goal or mutual profits (Heavey \& Murphy, 2012). Such cooperation is achieved by sharing knowledge, making decisions and reaching a consensus (Dietrich, Economics, Eskerod, Dalcher, \& Sandhawalia, 2010). This study concerns interpersonal cooperation, which relates to people working together in an organisation (Bond-Barnard, Fletcher, \& Steyn, 2018). To conclude, cooperation describes the collective action with which individuals pursue organisational goals.

The extant research has confirmed that there are links between trust and team cooperation (Fink, Kraus, 2007; Ruohomaa, Viljanen, \& Kutvonen, 2010; Radomska, Wołczek, Sołoducho-Pelc, \& Silva, 2019). Benson, Ribbers, and Blitstein (2014) identified the connection between trust and cooperation, implying that the degree of trust affects levels of collaboration in IT organisations. It has been demonstrated that trust nurtures collaboration and positive interpersonal relationships (Gordon \& Smith, 2015). Furthermore, trust is acknowledged as a necessary condition for successful team cooperation (Child, 2015). Concluding, it is assumed that effective interpersonal collaboration depends on trust.

It has been indicated that cooperation can be maintained successfully even without the presence of trust (Brache, 2018); however, the research mentioned above concerns cooperation at the inter-organisational level, whereas this study relates to cooperation and its impact on interpersonal relations within organisations. So, based on much research, it is assumed that interpersonal trust improves team cooperation (Pinho, 2012). For instance, Choi and Cho indicate that trust is a core factor that enables team cooperation (2019). Therefore, it has been hypothesised that:

$\mathrm{H} 2$ : Trust between coworkers is positively associated with team cooperation.

\subsection{The mediating role of team cooperation}

Cooperation involves social relations that enhance in-group cooperation and overall group effectiveness (Pitafiб Kanwal, Ali, Khan, \& Waqas Ameen, 2018); moreover, it has been confirmed that trust improves cooperation (Liao \& Long, 2018). Therefore, social relations are recognised as a significant factor in strengthening the cohesiveness of teams (Markova \& Perry, 2014). Social interactions play a significant role in creating effective team collaboration (Mason \& Lefrere 2003).

Additionally, social processes facilitate the transfer of tacit knowledge within organisations (Becerra-Fernandez \& Sabherwal, 2001). Shared experience is an essential aspect of the tacit knowledge sharing process (Nonaka \& Takeuchi, 1995). Interpersonal bonds facilitate the spread of tacit knowledge (Sun \& Scott, 2005). Some research demonstrates that knowledge transfer depends on the level of cooperation (Laycock, 2005). This is consistent with SCT, which states that knowledge can be created and shared through social interactions (Vygotsky, 1962). People can 

and interpersonal trust

understand and learn new information if they can relate to those who are giving it to them. By SCT, successful knowledge transfer within an organisation is contingent upon the mutual understanding of team members. Collaboration establishes an environment that through past experiences and social interaction enables inter-team relations to develop. Thus, collaboration enhances effective tacit knowledge transfer and serves as a moderating variable:

H3: Team collaboration mediates the relationship between trust and tacit knowledge transfer.

The conceptual framework and the connections between variables are illustrated in Figure 1.
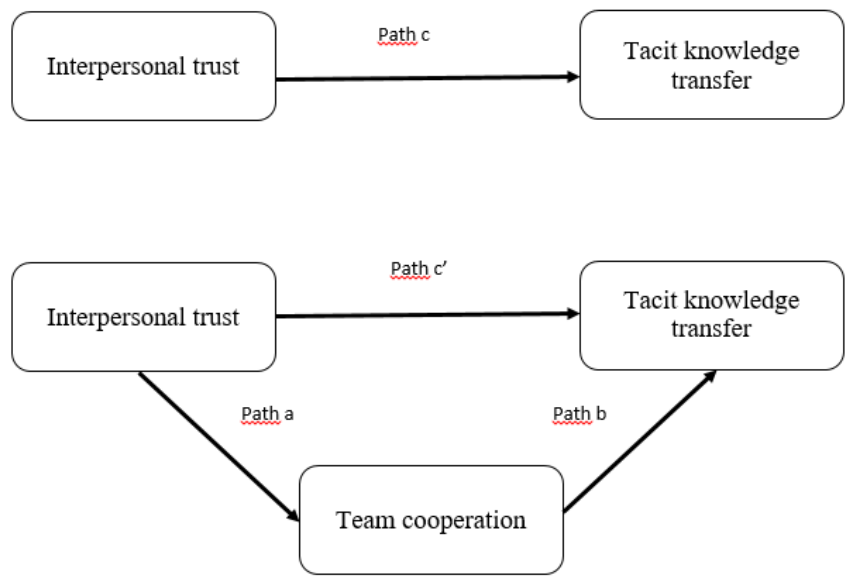

Figure 1. The conceptual framework of the study (source: created by the author, based on Fairchild and MacKinnon (2009))

\section{Research methodology}

\subsection{Sample}

The sample for this study consisted of 175 employees in telecommunication companies operating in Poland. The telecommunication sector in Poland is valued approximately around 39,5 billion PLN (according to the data provided by The Office of Electronic Communication for 2017). The telecommunication sector is one of the most profitable nonfinancial business in Poland. Furthermore, the telecommunication sector turnover is steadily growing. This industry is founded on innovative solutions and state-of-the-art infrastructure. Therefore, the role of intangible assets is vital in the telecommunication sector. The ability to successfully manage knowledge is crucial for telecommunication organisations. The employees from these companies work in a highly competitive environment which requires regular knowledge transfer. The use of tacit knowledge is necessary for them in order to perform their duties. The process of effective tacit knowledge transfer boosts employees' output.

The register of telecommunication companies maintained by The Office of Electronic Communication was used as a sample frame. The data were obtained from 175 employees working in the telecommunication industry in Poland.

Demographic of the research sample are as follows: $34.86 \%(61)$ of respondents were female and $64.14 \%(114)$ were male. $77.14 \%$ (135) respondents worked in large organizations (251 or more employees), $13.14 \%$ (23) in mediumsize companies (51-250 employees), 7.43\% (13) in small (11-50 employees) and 2.,29\% (4) in micro organizations (10 or less employees). 72\% (127) of survey participants work in Polish-owned organisation, while $72.57 \%$ (127) in international enterprises. $60 \%$ (105) of respondents had working experience of more than 10 years, $13.71 \%(24) 6-10$ years, $22.86 \%$ (40) between $1-5$ years and $3.43 \%$ (6) less than a year.

\subsection{Measures}

In order to measure the interpersonal trust (IT) independent variable, a 3-item instrument was used. Based on Forret and Love (2008) and Poon (2013), it includes the following statements: "Most of my co-workers can be relied upon to do their work", "Most of my co-workers are trustworthy", "I have confidence in my co-workers". The respondents were asked to express their agreement to a given statement using a five-point Likert scale ( 1 - strongly disagree, 2 disagree, 3 - neither agree or disagree, 4 - agree, 5 - strongly agree). The Cronbach's alpha for this item was $\alpha=0.76$.

Table 1. Construct reliability and validity (source: created by authors)

\begin{tabular}{|c|c|c|c|c|}
\hline Construct & Items & Cronbach's $\alpha$ & McDonald's $\omega$ & Kaiser-Meyer-Olkin test (KMO) \\
\hline IT & 3 & 0.769 & 0.777 & 0.681 \\
\hline TKT & 3 & 0.801 & 0.828 & 0.653 \\
\hline TC & 4 & 0.879 & 0.882 & 0.683 \\
\hline
\end{tabular}



and interpersonal trust

Dependent variable: Tacit knowledge transfer (TKT) (based on Shao et al., 2015) was measured using a 5-item Likert scale. The questions are as follows: "In my organisation people are pleased to communicate with other members their personal experience", "In my organisation, people like to share their expertise with other members" and "In my organisation people are willing to share know-how knowledge at the request of other members". The Cronbach's alpha for the scale measuring tacit knowledge transfer was $\alpha=0.81$.

The mediator, team cooperation (TC), was evaluated using a 4-item scale based on Stark, Bierly and Harper (2014). The respondents were asked to evaluate their responses using a five-point Likert scale referring to the following statements: "Team members find it easy to work with each other", "Team members are comfortable communicating with each other about what needs to be done", "Team members cooperate to get the work done", "Team members work well together to solve problems and make decisions". The Cronbach's alpha for this item was $\alpha=0.87$.

\subsection{Control variable}

The control variable was included in this study to account for individual differences among organisational members. Since some studies have confirmed the impact that generalised trust (GT) has on trust in economic institutions (Tan \& Tambyah, 2011) generalised confidence was also taken under consideration in this study.

\subsection{Procedure}

In 2018, the author distributed the questionnaire among 175 employees of telecommunications companies by e-mail and in a printed version. The headnote introduced the purpose of the study and confirmed the anonymity of the survey. 67 responses were obtained on paper and 108 via an online survey. The data was coded in Excel and analysed using Statistica 13.1 and R Studio. The tests included correlation analysis, descriptive statistics, and multiple linear regression analysis.

\subsection{Data analysis}

In order to verify the research hypotheses H1 and H2, regression analysis was conducted to analyse the links between interpersonal trust, tacit knowledge transfer, and team cooperation. The mediating effect of team cooperation on the trust and knowledge transfer relationship was verified using a four-stage method designed by Baron and Kenny (1986) which has the following conditions: (1) the independent variable (interpersonal trust) must be related to the mediator (team cooperation); (2) the mediator must be related to the dependent variable (tacit knowledge transfer); (3) the independent variable must not have an effect on the dependent variable when the mediator is included (full mediation), or its effect should be substantially reduced (partial mediation) (Kenny, Kashy, \& Bolger, 1998).

\section{Results}

\subsection{Descriptive statistics}

The means, standard deviation and Pearson's correlation among variables are given in table 2. The analysis implies links between interpersonal trust and tacit knowledge transfer. None of the correlations exceeds $r=0.50$, suggesting it is unlikely that it will bias the results of the regression analysis (Zimmerman, Zumbo, \& Williams, 2003). Further, the positive and statistically significant correlation has been verified between variables.

Table 2. Means, Standard Deviations and Correlation among study variables (source: created by authors)

\begin{tabular}{|c|c|c|c|c|c|c|}
\hline Variables & Mean & SD & 1 & 2 & 3 & 4 \\
\hline Generalised trust & 3.960 & 0.783 & 1.000 & & & \\
\hline Interpersonal trust & 4.040 & 0.729 & $0.425^{* *}$ & 1.000 & & \\
\hline Tacit knowledge transfer & 4.001 & 0.749 & 0.133 & $0.483^{* *}$ & 1.000 & \\
\hline Team cooperation & 3.985 & 0.797 & 0.091 & $0.504^{* *}$ & $0.438^{* *}$ & 1.000 \\
\hline
\end{tabular}

Notes: $\mathrm{N}=175 ; * *$ correlation is significant at $\mathrm{p}<0.01, *$ correlation is significant at $\mathrm{p}<0.05$

\subsection{Hypotheses testing}

Testing the $\mathrm{H} 1$ and $\mathrm{H} 2$ hypotheses, multiple regression analysis was conducted. $\mathrm{H} 1$ concerns the relationship between interpersonal trust and tacit knowledge transfer. Table 3 presents the results of regression analysis of $\mathrm{H} 1$.

These results support hypothesis H1. There is a positive association between interpersonal trust and tacit knowledge transfer $(\beta=0.459, \mathrm{p}<0.001)$. Trust explains $21.9 \%$ of the variance in tacit knowledge transfer. 

and interpersonal trust

$\mathrm{H} 2$ proposes a relationship between trust and team cooperation. The results support this hypothesis and indicate that interpersonal trust positively affects team cooperation $(\beta=0.430, p<0.001)$. This explains $20.1 \%$ of the variance. The results are presented in Table 4.

Table 3. Regression analysis of H1: interpersonal trust as a predictor of tacit knowledge transfer (path c) (source: created by authors)

\begin{tabular}{|c|c|c|c|c|c|}
\hline & \multicolumn{5}{|c|}{ Tacit knowledge transfer } \\
\hline Independent variables & $\mathrm{B}$ & $\mathrm{SE} \mathrm{B}$ & $\beta$ & $\mathrm{t}(172)$ & $\mathrm{p}$ \\
\hline Interpersonal trust & 0.492 & 0.079 & 0.459 & 6.174 & 0.000 \\
\hline Generalized trust & 0.021 & 0.074 & 0.021 & 0.285 & 0.775 \\
\hline $\mathrm{F}$ & \multicolumn{5}{|c|}{$0.24 .226^{* * *}$} \\
\hline $\mathrm{R}^{2}$ & \multicolumn{5}{|c|}{0.219} \\
\hline
\end{tabular}

Notes: $\mathrm{n}=175 ; * * \mathrm{p}<0.01 ; * * * \mathrm{p}<0.001$; B-unstandardized beta; SE B the standard error for the unstandardized beta; $\beta$ the standardized beta; $\mathrm{t}$ the $t$ test statistic; $\mathrm{p}$ the probability value.

Table 4. Regression analysis of $\mathrm{H} 2$ : team cooperation as a predictor of tacit knowledge transfer (path b) (source: created by authors)

\begin{tabular}{|c|c|c|c|c|c|}
\hline & \multicolumn{5}{|c|}{ Tacit knowledge transfer } \\
\hline Independent variables & $\mathrm{B}$ & $\mathrm{SE} \mathrm{B}$ & $\beta$ & $\mathrm{t}(172)$ & $\mathrm{p}$ \\
\hline Team cooperation & 0.404 & 0.064 & 0.430 & 6.284 & 0.000 \\
\hline Generalized trust & 0.090 & 0.065 & 0.094 & 1.385 & 0.167 \\
\hline $\mathrm{F}$ & \multicolumn{5}{|c|}{$0.21 .679 * * *$} \\
\hline $\mathrm{R}^{2}$ & \multicolumn{5}{|c|}{0.201} \\
\hline
\end{tabular}

Notes: $\mathrm{n}=175 ; * * \mathrm{p}<0.01 ; * * * \mathrm{p}<0.001$; B-unstandardized beta; SE B the standard error for the unstandardized beta; $\beta$ the standardized beta; $\mathrm{t}$ the $t$ test statistic; p the probability value.

Table 5. Regression analysis of interpersonal trust as a predictor of team cooperation (path a) (source: created by authors)

\begin{tabular}{|c|c|c|c|c|c|}
\hline & \multicolumn{5}{|c|}{ Team cooperation } \\
\hline Independent variables & $\mathrm{B}$ & $\mathrm{SE} \mathrm{B}$ & $\beta$ & $\mathrm{t}(172)$ & $\mathrm{p}$ \\
\hline Interpersonal trust & 0.621 & 0.078 & 0.568 & 7.918 & 0.000 \\
\hline Generalized trust & -0.153 & 0.073 & -0.150 & -2.096 & $0.037^{*}$ \\
\hline F & \multicolumn{7}{|c|}{$32.332 * * *$} & 0.273 \\
\hline R2 & \multicolumn{7}{|c|}{} \\
\hline
\end{tabular}

Notes: $\mathrm{n}=175 ; * * \mathrm{p}<0.01 ; * * * \mathrm{p}<0.001$; B-unstandardized beta; SE B the standard error for the unstandardized beta; $\beta$ the standardized beta; $\mathrm{t}$ the $t$ test statistic; $\mathrm{p}$ the probability value.

In order to verify the mediating effect of team cooperation on the relationship between interpersonal trust and tacit knowledge transfer, a 4-step analysis was conducted (Hayes, 2013). First, the relationship between interpersonal trust and tacit knowledge transfer (path c) was established. Secondly, the dependence on trust and team cooperation (path a) was found (Table 5). Thirdly the relation between team cooperation and tacit knowledge transfer (path b) was confirmed. Finally, the last step was conducted (path c'). When team cooperation was included in the regression analysis, the effect of interpersonal trust on tacit knowledge transfer was reduced, which supports hypothesis H3.

Table 6. Regression analysis of interpersonal trust as a predictor of team cooperation (path c') (source: created by authors)

\begin{tabular}{|c|c|c|c|c|c|}
\hline & \multicolumn{5}{|c|}{ Tacit knowledge transfer } \\
\hline Independent variables & $\mathrm{B}$ & $\mathrm{SE} \mathrm{B}$ & $\beta$ & $\mathrm{t}(172)$ & $\mathrm{p}$ \\
\hline Interpersonal trust & 0.237 & 0.071 & 0.253 & 3.341 & 0.001 \\
\hline Team cooperation & 0.386 & 0.085 & 0.376 & 4.513 & 0.000 \\
\hline generalized trust & -0.046 & 0.069 & -0.049 & -0.678 & 0.498 \\
\hline $\mathrm{F}$ & \multicolumn{5}{|c|}{0.286} \\
\hline $\mathrm{R}^{2}$ & \multicolumn{7}{|c|}{} \\
\hline
\end{tabular}

Notes: $\mathrm{n}=175 ;{ }^{* *} \mathrm{p}<0.01 ; * * * \mathrm{p}<0.001$; B-unstandardized beta; SE B the standard error for the unstandardized beta; $\beta$ the standardized beta; $\mathrm{t}$ the $t$ test statistic; $\mathrm{p}$ the probability value. 

and interpersonal trust

The summarised steps included in the path model are presented in Table 7. This analysis indicates that there was a $31 \%$ reduction of the total effect that interpersonal trust had on tacit knowledge transfer when team cooperation was included in the analysis. Taken together, the results suggest partial mediation.

A Sobel test (Sobel, 1982) was also performed to verify the significance of the indirect effect of the predictor viable according to Hayes and Preacher (2014). The unstandardized regression coefficient and standard errors were used. The Sobel test statistics $=4.946, \mathrm{Se}=0.050, \mathrm{p}<0.001$, which supports the significance of the indirect effect of interpersonal trust on tacit knowledge transfer through its relationship with team cooperation. Thus, team cooperation mediates the relationship between interpersonal trust and tacit knowledge transfer.

Table 7. Regression analysis of H3: The effect of team cooperation as a mediator between interpersonal trust and tacit knowledge transfer (source: created by authors)

\begin{tabular}{|c|c|c|c|c|}
\hline \multirow{2}{*}{ Independent variables } & Path a & Path b & Path c & Path c' \\
\cline { 2 - 5 } & $\mathrm{B}$ & $\mathrm{B}$ & $\mathrm{B}$ & $0.237^{* *}$ \\
\hline Interpersonal trust & $0.621^{* * *}$ & - & $0.492^{* * *}$ & $0.386^{* * *}$ \\
\hline Team cooperation & - & $0.404^{* * *}$ & - & -0.046 \\
\hline generalized trust & -0.153 & 0.090 & 0.021 & $22.872 * *$ \\
\hline $\mathrm{F}$ & $32.332 * * *$ & $21.679 * * *$ & $24.226^{* * *}$ & 0.286 \\
\hline $\mathrm{R}^{2}$ & 0.273 & 0.201 & 0.219 & \\
\hline$\Delta \mathrm{R}^{2}$ & \multicolumn{3}{|c|}{0.067} \\
\hline
\end{tabular}

Notes: $\mathrm{n}=175 ;{ }^{*} \mathrm{p}<0.01 ; * * * \mathrm{p}<0.001 ; \mathrm{B}$-unstandardized beta; SE B the standard error for the unstandardized beta; $\beta$ the standardized beta; $\mathrm{t}$ the $t$ test statistic; $\mathrm{p}$ the probability value.

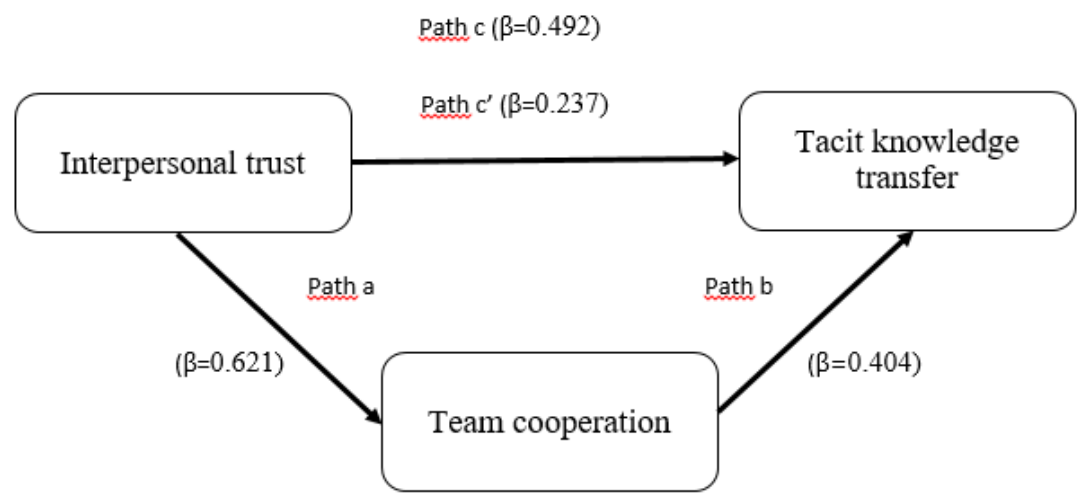

Figure 2. Unstandardized beta weights representing the mediated relationship between interpersonal trust and tacit knowledge transfer via team cooperation (source: created by authors)

Figure 2. illustrates the mediation analysis results by including the unstandardized regression coefficient for the paths a, b, c, and c'.

\section{Discussion}

Tacit knowledge transfer is considered a critical factor that supports organisational performance (Harlow, 2008). The significant contribution of this research is the establishment of links between interpersonal trust and tacit knowledge transfer. The multiple regression analysis suggests that interpersonal trust has a significant effect on tacit knowledge transfer (H1). Taken together, the results demonstrate that trusting relations with fellow employees facilitate tacit knowledge dissemination. The findings provide further evidence that supports the associations between interpersonal trust and tacit knowledge transfer (Foos et al., 2006). It implies that a trusting environment facilitates tacit knowledge sharing by encouraging interaction and allowing employees to learn (Bennet \& Bennet, 2008).

Moreover, the conducted data analysis confirmed that tacit knowledge transfer depends on team cooperation (H2). Further, the study explains the relationship between interpersonal trust and tacit knowledge transfer, mediated via team cooperation (H3). Drawing on SET and SCT, the research identified the linkage that enhances tacit knowledge transfer in organisations. 

and interpersonal trust

\section{Conclusions}

This research suggests that the sharing of tacit knowledge depends on interpersonal trust and team cooperation. In order to effectively manage knowledge in contemporary organisations successful knowledge transfer is vital. Knowledge workers' ability to create and use knowledge is related to their capacity to share it. The dissemination of knowledge leverages the quality of knowledge management. It is especially important concerning tacit knowledge. The tacit knowledge is difficult to codify and to convey. However, it concerns know-how and individual expertise. Therefore, the willingness of tacit knowledge sharing among employees is essential for successful knowledge application. The organisation should support tacit knowledge transfer. This research identifies the central aspect that facilitates the attitudes toward tacit knowledge transfer in organisations. This study suggests that the sharing of tacit knowledge depends on interpersonal trust and team cooperation. It indicates that trust is a core factor that enhances this process.

Additionally, it identifies the role of collective experience in developing the tacit knowledge sharing attitude among employees. Such a successful collaboration allows establishing the common understanding within a team which in turn enhances the knowledge transfer. Moreover, tacit knowledge can be successfully disseminated through collective experience and cooperative learning. Therefore, tacit knowledge transfer based on trust, but this relationship is mediated through team collaboration, which enables the ability to convey individual expertise and know-how.

The theoretical implication relates to the empirical confirmation of the SET-based model that concerns the mechanism of tacit knowledge transfer. This study confirms that knowledge transfer is a reciprocal process. Additionally, it provides an empirical verification that the linkage between interpersonal trust and tacit knowledge transfer is mediated by team collaboration. It suggests that collective experience establish a platform for such an exchange. It is in alignment with the SCT, which emphases the importance of mutual understating in the tacit knowledge sharing process. What is more, it confirms that highly personal tacit knowledge can be transferred based on collective experiences.

The practical implications highlight the importance of common collaborative experience and interpersonal trust that facilitates trust among coworkers and consequently influences tacit knowledge transfer. Additionally, team cooperation enhances tacit knowledge transfer. Since this research suggests that trust in fellow employees is the significant factor, creating an environment which encourages trust leads to improved tacit knowledge transfer in organisations. This study provides a guide for managers on how to foster trust-based relationship and motivate the team's engagement in collaborative experience, in order to enable tacit knowledge to be shared among employees. Additionally, it supports the importance of collective learning in the process of tacit knowledge transfer.

Further research should examine various additional variables that affect the relationship between trust and tacit knowledge transfer.

\section{References}

Al-Alawi, A. I., Al-Marzooqi, N. Y., \& Fraidoon Mohammed Y. (2007). Organizational culture and knowledge sharing: Critical success factors. Journal of Knowledge Management, 11(2), 22-42. https://doi.org/10.1108/13673270710738898

Baron R. M., \& Kenny, D. (1986). The moderator-mediator variable distinction in social psychological research: Conceptual, strategic, and statistical considerations. Journal of Personality and Social Psychology, 51(6), 1173-1182. https://doi.org/10.1037/0022-3514.51.6.1173

Becerra-Fernandez, I., \& Sabherwal, R. (2001). Organizational knowledge management: A contingency perspective. Journal of Management Information Systems, 18, 23-55. https://doi.org/10.1080/07421222.2001.11045676

Bachmann R., Gillespie N. \& Priem R. (2015). Repairing trust in organizations and institutions: Toward a conceptual framework. Organization Studies, 36(9), 1123-1142. https://doi.org/10.1177/0170840615599334

Benne, D., \& Bennet A. (2008). Engaging tacit knowledge in support of organizational learning. VINE, 38(1), $72-94$. https://doi.org/10.1108/03055720810870905

Benson, R. J., Ribbers P. M., \& Blitstein R. B. (2014). Trust and partnership: strategic IT management for turbulent times. Hoboken, New Jersey: Wiley.

Bennett, R. H. III (1998). The importance of tacit knowledge in strategic deliberations and decisions. Management Decision, 36(9), 589-97. https://doi.org/10.1108/00251749810239478

Blattberg, R., \& Hoch, S. (1990). Database models and managerial intuition: 50\% model $+50 \%$ intuition. Management Science, 36(8), 887-99. https://doi.org/10.1287/mnsc.36.8.887

Blau, P. M. (1964). Exchange and power in social life. New York, NY: Wiley.

Boateng, H., Agyemang, F. G., Okoe, A.F., \& Mensah, T. D. (2017). Examining the relationship between trustworthiness and students' attitudes toward knowledge sharing. Library Review, 66(1/2), 16-27. https://doi.org/10.1108/LR-05-2016-0046

Bond-Barnard, T. J., Fletcher L., \& Steyn H. (2018). Linking trust and collaboration in project teams to project management success. International Journal of Managing Projects in Business, 11(2), 432-457. https://doi.org/10.1108/IJMPB-06-2017-0068

Brache, J. (2018). The cooperation mechanisms of trade associations. Academia Revista Latinoamericana de Administración, 31(4), 701-718. https://doi.org/10.1108/ARLA-12-2016-0329

Brattström, A., \& Bachmann, R. (2017). Cooperation and coordination: The role of trust in inter-organizational relationships. In R. H. Searle, A. M. I. Nienaber \& S. B. Sitkin (Eds.), The Routledge Companion to Trust (pp. 129-142).

https://doi.org/10.4324/9781315745572 
Brockmann, E. N., \& Anthony W. P. (1998). The influence of tacit knowledge and collective mind on strategic planning. Journal of Managerial Issues, 10(2), 204-22. Retreived from https://www.jstor.org/stable/40604193

Brown, P., Hesketh A., \& Wiliams S. (2003). Employability in a knowledge-driven economy. Journal of Education and Work, 16(2), 107-126. https://doi.org/10.1080/1363908032000070648

Bruhn, J. G. (2001). Trust in Organizations. In J. G. Bruhn, Trust and health of organizations (pp. 35-51). New York, NY: Springer.

Bulińska-Stangrecka, H., \& Bagieńska, A. (2018). Investigating the links of interpersonal trust in telecommunications companies. Sustainability, 10(7), 1-17. https://doi.org/10.3390/su10072555

Burnette, M. (2017). Tacit knowledge sharing among library colleagues: a pilot study. Reference Services Review, 45(3), 382-397. https://doi.org/10.1108/RSR-11-2016-0082

Child, J. (2015). Generating and utilizing trust. Chichester, UK: Wiley.

Christie, A. M. H., Jordan, P. J., \& Troth, A. C. (2015). Trust antecedents: Emotional intelligence and perceptions of others. International Journal of Organizational Analysis, 23(1), 89-101. https://doi.org/10.1108/IJOA-07-2013-0695

Choi, O., \& Cho, E. (2019). The mechanism of trust affecting collaboration in virtual teams and the moderating roles of the culture of autonomy and task complexity. Computers in Human Behavior, 91(February 2019), 305-315. https://doi.org/10.1016/j.chb.2018.09.032

Choo, C. (2000). Working with knowledge: how information professionals manage what they know. Library Management, 21(8), 395-403. https://doi.org/10.1108/01435120010342770

Danielson, A., \& Holm, H. (2007). Do you trust your brethren?: Eliciting trust attitudes and trust behavior in a Tanzanian congregation. Journal of Economic Behavior \& Organization, 62(2), 255-271. https://doi.org/10.1016/j.jebo.2004.10.011

Davenport, T., De Long, D., \& Beers M. (1998). Successful knowledge management projects. Sloan Management Review, 39(2), 43-57.

DeLong, D. W. (2004). Lost knowledge: Confronting the threat of an ageing workforce. Oxford: Oxford University Press. https://doi.org/10.1093/acprof:oso/9780195170979.001.0001

Dietrich, P., Economics, B., Eskerod, P., Dalcher, D., \& Sandhawalia, B. (2010). The role of project collaboration quality and knowledge integration capability in multi-partner projects. Paper presented at PMI Research \& Education Conference, Washington DC, United States. Retreived from: http://researchprofiles.herts.ac.uk/portal/en/publications/the-role-of-knowledge-integration-capability-and-collaboration-quality-in-multipartner-projects(0ba9a9e2-32ba-467a-92dc-3277ff093094).html

Ejdys, J. (2018). Zaufanie do technologii w e-adminstracji. [Trust to technology in an e-administration], wydawnictwo PB, Białystok. Retrieved from https://depot.ceon.pl/bitstream/handle/123456789/16069/Zaufanie\%20do\%20technologii\%20w\%20e-administracji.pdf

Emerson, R. M. (1976). Social exchange theory. Annual Review of Sociology, 2, 335-362. https://doi.org/10.1146/annurev.so.02.080176.002003

Fairchild, A. J., \& Mackinnon, D. (2009). A general model for testing mediation and moderation effects. Prevention Science, 10(2), 87-99. https://doi.org/10.1007/s11121-008-0109-6

Ferguson, A. J., \& Peterson R. S. (2015). Sinking slowly: Diversity in propensity to trust predicts downward trust spirals in small groups. Journal of Applied Psychology, 100(4), 1012-1024. https://doi.org/10.1037/ap10000007

Fink, M., \& Kraus S. (2007). Mutual trust as a key to internationalization of SMEs. Management Research News, 30(9), 674-688. https://doi.org/10.1108/01409170710779980

Foos, T., Schum, G., \& Rothenberg, S. (2006). Tacit knowledge transfer and the knowledge disconnect. Journal of Knowledge Management, 10(1), 6-18. https://doi.org/10.1108/13673270610650067

Forret, M., \& Love, M. S. (2008). Employee justice perceptions and coworker relationships. Leadership \& Organization Development Journal, 29(3), 248-260. https://doi.org/10.1108/01437730810861308

Gomez, C., \& Rosen, B. (2001). The leader-member exchange as a link between managerial trust and employee empowerment. Group \& Organization Management, 26(1), 53-69. https://doi.org/10.1177/1059601101261004

Gomezelj, D.O., \& Antončič, B. (2015). Employees' knowledge determinants in SMEs: the case of Slovenia. Journal of Business Economics and Management, 16(2), 422-444. https://doi.org/10.3846/16111699.2012.734326

Gordon, J., \& Smith, M. (2015). You win in the locker room first: The 7 C's to build a winning team in business, sports, and life. New Jersey: Wiley.

Gouldner, A. (1960). The norm of reciprocity. American Sociological Review, 25, 161-178.

Grover, V., \& Davenport T. (2001). General perspective on knowledge management: fostering a research agenda. Journal of Management Information Systems, 18(1), 5-21. https://doi.org/10.1080/07421222.2001.11045672

Gupta, N., Ho V., Pollack J., \& Lai L. (2016). A multilevel perspective of interpersonal trust: Individual, dyadic, and cross-level predictors of performance. Journal of Organizational Behavior, 37(8), 1271-1292. https://doi.org/10.1002/job.2104

Haldin-Herrgard, T. (2000). Difficulties in diffusion of tacit knowledge in organizations. Journal of Intellectual Capital, 1(4). $357-$ 65.

Harlow, H. (2008). The effect of tacit knowledge on firm performance. Journal of Knowledge Management, 12(1), 148-163. https://doi.org/10.1108/13673270810852458

Hayes, A. F. (2013). Introduction to mediation, moderation, and conditional process analysis: A regression-based approach. New York, NY: Guilford Press.

Hayes, A. F., \& Preacher, K. J. (2014). Statistical mediation analysis with a multicategorical independent variable. British Journal of Mathematical and Statistical Psychology, 67, 451-470. https://doi.org/10.1111/bmsp.12028 
Heavey, C., \& Murphy, E. (2012). A proposed cooperation framework for organisations and their leaders. Management Decision, 50(6), 993-1000.

Hefferan, T. (2004). Trust formation in cross-cultural business-to-business relationships. Qualitative Market Research: An International Volume, 7(2), 114-125. https://doi.org/10.1108/13522750410530020

Holste, J.S., \& Fields D. (2010). Trust and tacit knowledge sharing and use. Journal of Knowledge Management, 14(1). 128-140. https://doi.org/10.1108/13673271011015615

Inkpen, A., Tsang, E. (2005). Social capital, networks, and knowledge transfer. The Academy of Management Review, 30(1), 146165. https://doi.org/10.5465/amr.2005.15281445

Johnson, D., \& Grayson, K. (2005). Cognitive and affective trust in service relationships. Journal of Business Research, 58(4), 500507. https://doi.org/10.1016/S0148-2963(03)00140-1

Joseph, E., \& Winston, B., (2005). A correlation of servant leadership, leader trust, and organizational trust. Leadership \& Organization Development Journal, 26(1), 6-22. https://doi.org/10.1108/01437730510575552

Kenny, D., Kashy D., \& Bolger, N. (1998). Data analysis in social psychology. In D. Gilbert, S. Fiske \& G. Lindzey (Eds.), Handbook of social psychology (4th ed., pp. 233-265). New York, NY: McGraw-Hill.

Kogut, B., \& Zander, U. (1996). What firms do? Coordination, identity and learning. Organizational Science, 7(5), 502-518. https://doi.org/10.1287/orsc.7.5.502

Kong, D., Dirks, K., \& Ferrin, D. (2014). Interpersonal trust within negotiations: Meta-analytic evidence, critical contingencies, and directions for future research. Academy of Management Journal, 57(5), 1235-1255. https://doi.org/10.5465/amj.2012.0461

Kumar, A., \& Ganesh, L. (2009). Research on Knowledge Transfer in Organizations: A Morphology. Journal of Knowledge Management, 13(4),161-174. https://doi.org/10.1108/13673270910971905

Laycock, M. (2005). Collaborating to compete: Achieving effective knowledge sharing in organizations. The Learning Organization, 12(6), 523-538. https://doi.org/10.1108/09696470510626739

Liao, Z., \& Long, S. (2018). Can interfirm trust improve firms' cooperation on environmental innovation? The moderating role of environmental hostility. Business Strategy and the Environment, 28(2), 1-8. https://doi.org/10.1002/bse.2249

Lohikoski, P. Kujala, J., Haapasalo, H., Aaltonen, K., \& Ala-Mursula, L. (2016). Impact of trust on communication. IJKBO International Journal of Knowledge-Based Organizations, 6(1), 1-19. https://doi.org/10.4018/IJKBO.2016010101

Luo, B. N., Lui, S. S., \& Kim, Y. (2017). Revisiting the relationship between knowledge search breadth and firm innovation: A knowledge transfer perspective. Management Decision, 55(1), 2-14. https://doi.org/10.1108/MD-07-2015-0327

Markova, G., \& Perry, J. T. (2014). Cohesion and individual well-being of members in self-managed teams. Leadership \& Organization Development Journal, 35(5), 429-441. https://doi.org/10.1108/LODJ-04-12-0058

Mason, J., \& Lefrere, P. (2003). Trust, collaboration, e-learning and organisational transformation. International Journal of Training and Development, 7(4), 259-270. https://doi.org/10.1046/j.1360-3736.2003.00185.x

Mayer, R., Davis, J., \& Schoorman, D. (1995). An integrative model of organizational trust. The Academy of Management Review, 20(3), 709-734.

McAllister, D. (1995). Affect- and cognition-based trust as foundation for interpersonal cooperation in organziations. Academy of Management Journal, 38(1), 24-59. https://doi.org/10.2307/256727

McEvily, B., Zaheer A., \& Kamal, D. (2017). Mutual and exclusive: Dyadic sources of trust in interorganizational exchange. Organization Science, 28(1), 74-92. https://doi.org/10.1287/orsc.2016.1102

McEvily, B., \& Tortoriello, M. (2011). Measuring trust in organizational research: Review and recommendations. Journal of Trust Research, 1(1), 23-63. https://doi.org/10.1080/21515581.2011.552424

Metzger, M. J. (2004). Privacy, trust, and disclosure: Exploring barriers to electronic commerce. Journal of Computer-Mediated Communication, 9(4). https://doi.org/10.1111/j.1083-6101.2004.tb00292.x

Morgan, R., \& Hunt, S. D. (1994). The commitment-trust theory of relationship marketing. Journal of Marketing, 58(3), 20-38. https://doi.org/10.1177/002224299405800302

Ng, M. (2016). Examining social exchange among Chinese service workers: The mediating effect of trust in organization, AsiaPacific Journal of Business Administration, 8(2), 163-176. https://doi.org/10.1108/APJBA-12-2015-0102

Niu, K. (2010). Organizational trust and knowledge obtaining in industrial clusters. Journal of Knowledge Management, 14(1), 141155. https://doi.org/10.1108/13673271011015624

Nonaka, I., \& Takeuchi, H. (1995). The knowledge-creating company: How Japanese companies create the dynamics of innovation. New York, NY: Oxford Universities Press.

Osinski, M., Selig, P. M., Matos, F., \& Roman, D. J. (2017). Methods of evaluation of intangible assets and intellectual capital. Journal of Intellectual Capital, 18(3), 470-485. https://doi.org/10.1108/JIC-1220160138

Pathirage, C., Amaratunga D., \& Haigh R. (2007). Tacit knowledge and organisational performance: construction industry perspective. Journal of Knowledge Management, 11(1), 115-126. https://doi.org/10.1108/13673270710728277

Pinho, J. C. M. R. (2012). Modelling the impact of commitment-trust on cooperation and performance: The specific case of exporter and intermediaries relationships. In K. Scott Swan \& S. Zou (Eds.), Interdisciplinary approaches to product design, innovation, \& branding in international marketing (pp. 243-265). Emerald Group Publishing Limited.

Pitafi, A. H., Kanwal, S., Ali, A., Khan, A. N., \& Waqas Ameen, M. (2018). Moderating roles of IT competency and work cooperation on employee work performance in an ESM environment. Technology in Society, 55, 199-208. https://doi.org/10.1016/j.techsoc.2018.08.002.

Polanyi, M. (1966). The tacit dimension. Garden City, NY: Doubleday. 
Poon, J. M. L. (2013). Effects of benevolence, integrity, and ability on trust-in-supervisor. Employee Relations, 35, 396-407. https://doi.org/10.1108/ER-03-2012-0025

Radomska, J., Wołczek, P., Sołoducho-Pelc L., \& Silva, S., (2019). The impact of trust on the approach to management - a case study of creative industries. Sustainability, 11(3), 816. https://doi.org/10.3390/su11030816

Raport o stanie rynku telekomunikacyjnego w Polsce w 2017 [Report on the state of the telecommunications market in 2017, Office of Electronic Communication]. Retrieved from https://www.uke.gov.pl/.../raport_o_stanie_rynku_telekomunikacyjnego_2017_r

Raudeliūnienè, J., Meidutè-Kavaliauskienè, I., \& Vileikis, K. (2016). Evaluation of factors determining the efficiency of knowledge sharing process. Journal of the Knowledge Economy, 7(4), 842-857. https://doi.org/10.1007/s13132-015-0257-4

Roloff, M. E. (1981). Interpersonal Communication: The Social Exchange Approach. Beverly Hills, CA: Sage.

Ruohomaa, S., Viljanen, L., \& Kutvonen, L. (2006). Guarding enterprise collaborations with trust decisions - the TuBE approach. In H. Panetto \& N. Boudjlida (Eds.), Interoperability for Enterprise Software and Applications. Paper presented at the Workshops and the Doctorial Symposium of the Second IFAC/IFIP I-ESA International Conference: EI2N, WSI, IS-TSPQ 2006. https://doi.org/10.1002/9780470612200.ch20

Rutten, W., Blaas-Franken, J., \& Martin, H. (2016). The impact of (low) trust on knowledge sharing. Journal of Knowledge Management, 20(2), 199-214. https://doi.org/10.1108/JKM-10-2015-0391

Sankowska, A., \& Siudak, D. (2016). The small world phenomenon and assortative mixing in polish corporate board and director networks. Physica A: Statistical Mechanics and its Applications, 443, 309-315. https://doi.org/10.1016/j.physa.2015.09.058

Savolainen, T., \& Häkkinen, S. (2011). Trusted to lead: Trustworthiness and its impact on leadership. Technology Innovation Management Review, March, 52-56.

Shao, Z., Wang, T., \& Feng, Y. (2015). Impact of organizational culture and computer self-efficacy on knowledge sharing. Industrial Management and Data Systems, 115(4), 590-611. https://doi.org/10.1108/IMDS-12-2014-0377

Smaliukienė, R., Bekešienė, S., Chlivickas, E., \& Magyla, M. (2017). Explicating the role of trust in knowledge sharing: A structural equation model test. Journal of Business Economics and Management, 18(4), $758-778$. https://doi.org/10.3846/16111699.2017.1317019

Smith, E. A. (2001). The role of tacit and explicit role in the workplace. Journal of Knowledge Management, 5(4), $311-21$. https://doi.org/10.1108/13673270110411733

Sobel, M. E. (1982). Asymptotic confidence intervals for indirect effects in structural equation models. Sociological methodology, 13, 290-312. https://doi.org/10.2307/270723

Stark, E., Bierly, P., \& Harper, S. R. (2014). The interactive influences of conflict, task interdependence and cooperation on perceptions of virtualness in co-located teams. Team Performance Management, 20(5/6), 221-241. https://doi.org/10.1108/TPM-06-2013-0020

Stranes, B., Truhon, S., \& McCarthy, V. (2016). Trust organizational trust: employee-employer relationships. A Primer on Organizational Trust, 1-16.

Sun, P., \& Scott, J. (2005). An investigation of barriers to knowledge transfer. Journal of Knowledge Management, 9(2), 75-90. https://doi.org/10.1108/13673270510590236

Tan, S. J., \& Tambyah, S. K. (2011). Generalized trust and trust in institutions in Confucian Asia. Social Indicators Research, 103(3), 357-377. https://doi.org/10.1007/s11205-010-9703-7

Verburg, R. M., Nienaber, A. M., Searle, R. H., Weibel, A., Den Hartog, D. N., \& Rupp, D. E. (2018). The role of organizational control systems in employees' organizational trust and performance outcomes. Group \& Organization Management, 43(2), 179-206. https://doi.org/10.1177/1059601117725191

von Krogh, G., Ichijo, K., \& Nonaka, I. (2000). Enabling knowledge creation-how to unlock the mystery of tacit knowledge and release the power of innovation. New York, NY: Oxford University Press. https://doi.org/10.1093/acprof:oso/9780195126167.001.0001

Vygotsky, L. S. (1962). Thought and language (Trans. by E. Hanfmann and G. Vakar). Cambridge, MA: MIT Press. https://doi.org/10.1037/11193-000

Wang, Z., \& Wang, N. (2012). Knowledge sharing, innovation and firm performance. Expert Systems with Applications: An International Journal Archive, 39(10), 8899-8908. https://doi.org/10.1016/j.eswa.2012.02.017

When, U., \& Montalvo, C. (2018). Knowledge transfer dynamics and innovation: Behaviour, interactions and aggregated outcomes. Journal of Cleaner Production, 171, 56-68. https://doi.org/10.1016/j.jclepro.2016.09.198

Yin, M., \& Jahanshahi, A. A. (2018). Developing knowledge-based resources: the role of entrepreneurs' social network size and trust. Sustainability, 10(10). https://doi.org/10.3390/su10103380

Zawiła-Niedźwiecki, J. (2015). Structuring knowledge management - classical theory, strategic initiation and operational knowledge management (Part I). Foundations of Management, 7(1), 253-266. https://doi.org/10.1515/fman-2015-0041

Zhao, J., Zhu, C., Peng, Z., Xu, X., \& Liu, Y. (2018). User willingness toward knowledge sharing in social networks. Sustainability, 10(12), 4680. https://doi.org/10.3390/su10124680

Zimmerman, D. W., Zumbo, B. D., \& Williams, R. H. (2003). Bias in estimation and hypothesis testing of correlation. Psicológica, 24, 133-158. 